\title{
Problems Faced by Preservice Special Education Teachers in Jordan
}

\author{
Ghaleb M. Al-Hiary ${ }^{1}$, Hisham A. Almakanin ${ }^{2} \&$ Suha A. Tabbal ${ }^{3}$ \\ ${ }^{1}$ Department of Special Education, College of Education, Alhussein Bin Talal University (AHU), Ma'an, Jordan \\ ${ }^{2}$ Department of Special Education, Queen Rania Faculty for Childhood, The Hashemite University. Al-Zarqa, \\ Jordan \\ ${ }^{3}$ The National Council for Family Affairs, Amman, Jordan \\ Correspondence: Ghaleb M. Al-Hiary, Department of Special Education, College of Education, Alhussein Bin \\ Talal University (AHU), P.O. Box 2297, Aljubiha, Amman 11941, Jordan. Tel: 962-776-426-199; \\ 962-797-246-175. E-mail: Ghaleb_alhiary@hotmail.com; ghaleb@ahu.edu.jo
}

\author{
Received: May 5, 2014 Accepted: November 4, 2015 Online Published: January 28, 2015 \\ doi:10.5539/ies.v8n2p128 URL: http://dx.doi.org/10.5539/ies.v8n2p128
}

\begin{abstract}
One of the most important factors in the success of educating children with special needs is the quality of the special education teacher. While teachers are responsible for a plethora of duties, it is important that teacher preparation programs provide adequate training to ensure teachers are well prepared for the teaching profession. However, previous research has found that teachers are not being adequately trained and consequently, they are experiencing problems within the classroom. Therefore, the current study aimed to investigate whether the gender of the preservice teacher, type of disability being taught, type of training institution, the university that the preservice teacher attends, and the number of hours credited for practicum training effects on the presence of five problem domains: training institution, problems related to university program, trainers/instructors, practicum plan and its requirements, and preservice teachers; and whether there was overall differences on the presence of the problems in general.

A survey was developed and distributed to preservice teachers completing their practicum in four public universities in Jordan. A total of 148 responded to the survey. Different statistical procedures were used to investigate the study's questions. Findings suggest the existence of differences between groups on types of disability being taught, types of training institution, university student currently attending, and number of hours credited for practicum training. Results were discussed and recommendations were made.
\end{abstract}

Keywords: special education, preservice special education teachers, teacher education, practicum training, Jordan

\section{Introduction}

One of the most important factors in the success of educating children with special needs is the quality of the special education teacher. Teachers are responsible for many duties that include: teaching, identification of strengths and weaknesses, developing IEPs, monitoring progress, assessment, and other duties. In order for teachers to comply with these duties, they need to be appropriately trained and strong professionals. Strong professionals are described as "relatively large, complex, rapidly growing body of professional knowledge requiring years of sustained study for its mastery" (Fueyo, Koorland, \& Rasch, 2008, p. 2). To be a professional teacher, it is a long, rapidly growing process comprised of both professionalization; meaning the process by which the occupation of teaching becomes a profession; and professionalism, the way members of a profession incorporate their "obligations with their knowledge and skill in a context of collegiality and contractual and ethical relations with clients" (Sockett, 1990, p. 36).

A strong professional program is achieved when it responds to knowledge production and scholarly norm rather than market driven and content knowledge approaches (Fueyo, Koorland, \& Rasch, 2008). However, Carnine (1992) indicates that strong professionals scientific knowledge bases supplement professionals with the needed expertise and confidence to be effective. Indeed, researchers desire to establish the connection between knowledge production and professional teacher preparation program development through providing teachers with professional skills of both education (content knowledge) and training (pedagogical content knowledge) (Grant \& Gillette, 2006). 


\subsection{Importance of Practicum Training}

Research indicates that field experiences have a positive effect on the knowledge and skills of special and general education preservice teachers in several ways (Hanline, 2010). The field experiences allow the content of knowledge learned in academic courses work take on a real meaning (Whitney, Golez, Nagel, \& Nieto, 2002). Additionally, these experiences allow the training teacher to develop better understandings of the teaching-learning process (McLoughlin \& Maslak, 2003; O’Brian, Stoner, Appel, \& House, 2007), and improve the learning of skills essential to individualized instruction (Sears, Cavallaro, \& Hall, 2004).

Field experiences are usually achieved through practicum training that are devised by teacher preparation programs. Teacher preparation programs should be extensive, well-planned, and well-supervised field experiences (Brownell, Ross, Colon, \& McCallum, 2005). Brownell and his colleagues also found four common features shared by exemplary special and regular education programs: (a) collaboration that includes faculty-candidate collaboration, or among and between professionals; (b) evaluation of program effectiveness, candidate performance, or both; (c) a focus on inclusion and cultural diversity; and (d) documented impact on student learning.

In recent years, heavy criticism is being placed on teacher education programs and their role of producing high quality teachers supported by the evidence that subject matter knowledge and high verbal ability characterize effective teachers who succeeds with the greatest student achievement gains. These factors have pushed toward redefining high quality special education teachers (Goe, 2007). Today, there is an increased attention emphasized on the quality of teachers (CEC, 2004). Several professional and governmental organizations in the United States and around the world have developed standards to ensure the quality of teachers being placed in special education classrooms or any other placement (e.g. Council for Exceptional Children (CEC), U.S. department of Education, Association of Teacher Educators (ATE), and higher education accreditation authorities). Further, $\mathrm{CEC}$, the largest global special education organization, suggests the minimum of a bachelor degree and emphasizes the role of pedagogy or teaching skills. CEC suggest a continuum of professional preparation for special education teachers that starts with the initial preparation, or preservice training (CEC, 2004).

\subsection{Previous Studies}

Some researchers attempted to understand the relationship between various teacher characteristics and students' achievement, or what is thought to make a high quality teacher. Aptitude, experience, coursework, degree earned, and certification are among those characteristics (Brownell, Leko, Kamman, \& King, 2008). Despite the lack of studies on teacher quality, what we do know about the characteristics, knowledge, beliefs, and practices of highly qualified teachers can be used as a starting-point of how to prepare a high-quality special education teacher (Brownell et al., 2008).

It is essential to conclude that initial preparation programs must be designed to promote the knowledge, beliefs, and classroom practices that characterize effective teaching. Unfortunately, we currently have insufficient information on how we might best prepare special and general education teachers initially. Most literature found focuses on the impact of single courses, pedagogy deployed within a course, or field work experiences; which all yield mixed results (Clift \& Brady, 2005).

Of the few comprehensive studies found in the literature investigating exemplary teacher education programs, Wideen, Mayer-Smith, and Moon (1998) reviewed 97 studies focused on preservice programs of pre-service learning to teach students from diverse cultural and linguistic backgrounds. They found that teacher education experiences that produces changes regarding diverse students have specific features in common, they include: (a) The use of pedagogical practice, (b) a programmatic approach to change beliefs, (c) faculty-student collaboration within a small group, (d), adhesion within a strong programmatic vision, and (e) a collaborative and planned field experiences by university and schools.

Darling-Hammond (2000) and the International Reading Association (2003) reviewed 15 programs known for documented effectiveness of their success in preparing teachers working with diverse learners, and found several characteristics among these programs. These characteristics include (a) a coherent program vision aligns different program experiences; (b) an active combination of theory, disciplinary knowledge, and subject matter knowledge and practice in coursework and field experiences; (c) carefully planned field experiences; (d) well-established standards for ensuring quality teaching for all students including diverse students; (e) active pedagogy employing modeling and fostering reflection; (f) a strong focus on meeting the needs of diverse students; and (g) collaboration to build a professional community. These characteristics seem to have the effect of prompting other essential aspects of teacher quality, such as effective classroom practices, according to researchers. 
Prior to the Persons with Disabilities law (Jordan) in 1993, individuals with disabilities were the responsibility of the Ministry of Social Development (MOSD). This law shifted most services to the Ministry of Education (MOE) and public schools. Consequently, MOE established a special education division and, slowly, implemented a resource room model in its schools (Al Khatib, 2007). Many private schools are implementing the resource room model as well. However, there are some students still served in some special education centers that are administrated and supervised by the MOSD; some other centers are administrative by the private sector, but supervised by MOSD.

Thousands of students are being served today by more qualified resource room teachers, thousands others are enrolled in regular schools without any organized assistance from both general and special education teachers (Al Khatib, 2007; Al-Bataineh, 2002). Additionally, many of those resource room teachers are coming from various educational fields such as language arts, mathematics, arts, etc. without or with poor preparation to teach students with special needs (Al-Hiary \& Kinnison, 2008). Al-Bataineh (2002) suggested that Jordan needs more comprehensive policies to meet the needs of students with disabilities through the recruiting of more qualified teachers, development of in-service training, and increased funding of special education.

Currently, in Jordon there are five public universities that have special education teacher preparation programs (preservice special education teacher programs); only four of them have students on their senior level where students are completing their practicum. Additionally, three private universities provide similar programs. Several public and private universities are planning to have such programs in the near future. Moreover, several community colleges provide 2-year preservice programs.

A comprehensive search for research studies regarding preservice teachers in Jordan and the Arab world revealed few results. Further, a very limited number of studies researched inservice training were found; mainly investigating the need for inservice training and the effect of an inservice training program (e.g. Hadidi, 1990, 1993). Other studies on teachers focused on other aspects of the teacher profession such as morals and attitudes (e.g. Smadi \& Nahar, 2001).

Nevertheless, one study conducted by Al-hiary and Kinnison (2008) compared preservice and inservice special education preparation programs in Jordan and the United States. After reviewing the degree-plans of the five public universities in Jordan, it was noted that these universities have the minimum of 123 credited hours of coursework that emphasize pedagogy, psychology, special education categories, at least one class in methods, and another in diagnosis. All these programs have at least one semester of practicum with 12 credited hours or two semesters with 3 to 6 credited hours each. Although these degrees were modified to be 132 credited hours, the content remained almost the same. The study found that most of these programs, as in the U.S., emphasize the acquisition of knowledge and theoretical issues rather that field-based experiences. The same conclusion can be found in other western universities (Carroll, 2003), but it is more pronounced in Jordan (Al-Khatib, 2007).

These institutes and universities providing special education preservice training are under heavy criticism. The current outcomes of students with disabilities are far behind than expected. Additionally, the educational reform is investigating all aspects of educational outcome for both regular and special students as a result of the disappointing results. Yahia (2006) reviewed several preservice training programs and concluded that preservice teachers expressed a general dissatisfaction of the content of their preservice training programs. She reported that several authorities attributed this dissatisfaction to problems the trainers faced doing practicum. However, she was not specific about types of problem trainers experienced.

Brownell et al. (2008) indicate that effective special education teachers have to possess knowledge of the specific academic and behavioral needs of their students with disabilities, as well as knowledge of explicit instruction tailored to their students needs. Further, Englert, Tarrant, and Mariage (1992) list features that distinguish special education teachers, which include ability to manage classroom behavior and to build a classroom community. Regardless, Brownell et al. (2008) found that research, to date, in general and special education at pre- and in-service levels, suggests that content knowledge and the ability to enact this knowledge are distinctive features of an effective teacher. In Jordan, universities and MOE are not any different: The effective teacher is the one who enact knowledge in his classroom.

Consequently, Brownell et al. (2008) concluded that there are several difficulties documented in the literature presenting the challenges in developing high-quality special education teachers. Difficulties include dimensions of teacher quality, lacking conceptual frameworks linking preparation programs to teacher quality outcome, and contextual issues in teacher education institutions and schools.

Broader view of teacher quality of special education teacher leads to findings of significant variations in teacher preparation programs. For example, Goe (2007) indicated that variations in special education preparation 
programs is substantial and those graduates' knowledge and beliefs may differ significantly depending on where they happened to have completed their coursework due to the lack of conceptual clarity of their programs.

Although the practicum is of great importance in teacher preparation programs; Edwards (1993), MacDonald (1993), and D'Rozario and Wong (1998) indicate that it is one of the most stressful times pre-service teachers face during their lives due of the many obstacles they encounter. There is a consensus in the field of education, including special education, that studying several courses in such programs is not enough guarantee to the success of education profession (Ysseldyke \& Algozzine, 1982; Warger \& Aldinger, 1984).

Hanline (2010) investigated several factors related to the field experiences in an early childhood special education program (ECSE) preservice teachers. Among these factors was issues faced by those training teachers. The study found that preservice teachers are most directly affected by experience and implies that the field experience must be carefully structured to meet the trainers needs, and must encompass all aspects of the professional role that special education professionals must acquire. Moreover, most teachers felt less prepared to take on challenges and roles related to collaboration, working with families, and obtaining administrative support.

Practicum training may impose several difficulties that may affect the quality of training provided for preservice teachers (e.g. El Astal, 2004; Embabi, 2002; Al-Qemesh \& Al-kharabsheh, 2009). Preham (1984) classified these problems into three types: problems related to trainees (student teachers), problems related to training programs, and problems related to trainers (supervisors). Guyton and McIntyre (1990) found that several problems are being faced by student teachers that include the unclear program goals, lack of communication between university and school where students are completing their practicum, short-term training period, lack of student teacher's skills in term of preparing and teaching their students, and uncompetitive supervising teacher.

Of the few studies in Jordan investigating factors related to practicum training in general and special education in specific, Zeitone and Obidat (1984) found a significant positive correlation between practicum practices and theoretical study in $78.2 \%$ of their Jordanian sample; the same significant positive correlation was found between practicum practices and special education teaching methods.

In his study in Saudi Arabia, Alghoni (1990) identified several obstacles that stand between preservice teachers and their effective training. Many students did not have enough time to do their practicum since that they take other classes at the same time; others have not found enough resources and conditions to improve their performance; and some others indicated that there was a lack of cooperation between school/training institute and preservice teachers.

Ammar (1997) indicates the most important problems faced by preservice teachers in the University of Damascus are the incompatibility between theoretical classes and the practicum program; the short period of practicum, and difficulties related to trainer (supervisor) such as: inaccuracy, carelessness, and lack of supervision. Diab (1999) found many of the same problems that the previous studies concluded among his Jordanian sample; however, he also reported students' lack of commitment to practicum training since many students are still attending theoretical classes at the same time.

Two studies investigated the role of the cooperative teacher (schoolteacher) in preparing future teachers. Al-Qahtani (1994) found that a cooperative teacher has a "moderate" role, especially in providing necessary experiences and teaching skills; the cooperative teachers had no knowledge of their role, and did not follow up with their preservice teachers. Al-Qahtani's finding may be attributed to the lack of professional skills of many special education teachers. Osunde (1996) found a significant effect for cooperative teacher on preservice teachers' performance, especially in teaching practices and arranging environment. Further, Al-Qemesh and Al-kharabsheh (2009) confirmed that cooperating teachers have influences that affect the quality of practicum training students' receive. It is clear that cooperative teacher can play a positive role enhancing practicum experience, depending on their professional level.

\subsection{Conclusion}

Based on the previous literature review, the researchers concluded that problems may face preservice special education teachers can be clustered into five domains:

A. Problems related to training institution (school, special education day-care centers, residential special education center, etc),

B. Problems related to university program,

C. Problems related to special education trainers/instructors, 
D. Problems related to practicum plan and its requirements, and

E. Problems related to trainees (preservice teachers).

These five problemswill serve as a framework for this study. Studies found in the literature are limited to one or few of these domains. Additionally, very few studies found in the world in general, and in Jordan and the Arab world specifically focusing on the nature and the quality of preservice teacher preparation programs. Thus, the current study is targetingproblems may be faced by preservice special education teachers.

\section{Method}

\subsection{Instrumentation}

Based on this conclusion, the author developed a survey of two parts. Part I contains demographic data (respondent name or initials, gender, type of disability(s) being taught (mental retardation, learning disabilities, and other types of disability), type of training institution (resource room (public or private school), special education centers (public or private), university student currently enrolled (University of Jordan (JU), Balqa Applied University (BAU), Mutah University (MU), and Alhussein Bin Talal University (AHU), and number of hours credited for practicum (3, 6, or 12 credit hours).

Part II consisted of four-point Likert-type scale survey. The survey was sent to several faculty members at different universities, including participant universities and practicum trainers/instructors. After reviewing the comments and suggestions, part II composed of 82 items distributed between the five domains mentioned earlier. Respondents were asked to express the presence of each problem (each item presented a problem) on four alternatives: Don't agree, mildly agree, moderately agree, and strongly agree.

\subsection{Study Questions}

The study aimed to investigate whether gender factor, type of disability being taught, type of training institution, university student currently attending, and number of hours credited for practicum training have effects on the presence of the five problem domains; and whether there was overall differences on the presence of the five problem domains (problems in general).

\subsection{Sample and Participants' Selection}

Three hundred surveys were sent to the four participating universities to be distributed in the second academic semester of the academic year 2010/2011. At the time of the study, only four public university have preservice special education teacher preparation programs. Surveys were given to all practicum (preservice) students in the four universities mentioned above. The total number of surveys distributed in each university depended on the number of students enrolled that semester; meaning it was not equally distributed. Additionally, the survey was distributed at the end of semester (practicum training) so that the respondents will have a better subjective response. The supervisors of practicum training distributed surveys on their final meeting with students. Respondents were informed of their rights of privacy and the choice of not responding. A total of 148 (49.3\%) participants responded to the survey; 61 males (41.2\%) and 87 females (58.8\%). Table 1 presents respondents' demographic information. Furthermore, reliability coefficients were calculated using two methods: Test-Retest and Cronbach's Alpha; Table 2 presents reliability coefficient measures information. As may be seen in Table 2, all five domains and the overall score were 0.75 or higher. Problems related to the university programs had the lowest Cronbach's Alpha reliability, but next to the highest test-retest reliability. 
Table 1. Respondents' demographic information

\begin{tabular}{lll}
\hline & Number & Percentage \% \\
\hline Type of disability teaching & & \\
\hline MR & 43 & $29.1 \%$ \\
LD & 68 & $45.9 \%$ \\
Other (HI, Health, VI, ASD) & 37 & $25 \%$ \\
\hline Type of training institution & & \\
\hline Public school/resource room & 52 & $35.1 \%$ \\
Private school/resource room & 22 & $14.9 \%$ \\
Public special education center & 29 & $19.6 \%$ \\
Private special education centers & 45 & $30.4 \%$ \\
\hline University student enrolled & & \\
\hline University of Jordan (JU) & 51 & $34.5 \%$ \\
Albalqa Applied University (BAU) & 27 & $18.2 \%$ \\
Mutah University (MU) & 35 & $23.6 \%$ \\
Alhussein Bin Talal University (AHU) & 35 & $23.6 \%$ \\
\hline Credited hours (Cr.H) & & \\
\hline 3 Cr.H & 1 & $0.7 \%$ \\
4 Cr.H & 1 & $0.7 \%$ \\
6 Cr.H & 55 & $37.2 \%$ \\
12 Cr.H & 91 & $61.5 \%$ \\
\hline Total & 148 & $100 \%$ \\
\hline
\end{tabular}

Table 2. Reliability coefficient measures

\begin{tabular}{lll}
\hline Domain & Test-Retest & Cronbach's Alpha \\
\hline Problems related to training institution & 0.95 & 0.85 \\
Problems related to university program & 0.94 & 0.75 \\
Problems related to special education trainers/instructors & 0.95 & 0.90 \\
Problems related to practicum plan and its requirements & 0.71 & 0.83 \\
Problems related to trainees & 0.72 & 0.81 \\
Overall Reliability & 0.87 & 0.94 \\
\hline
\end{tabular}

\section{Results}

A t-test was used to investigate the gender factor and yielded no significant differences on the presence of the five problem domains between gender groups; likewise, there were no overall differences in the existence of the five domain problems. Another ANOVA test was used to determine the existence of any differences between groups of students teaching various types of disability during their training. ANOVA results revealed significant differences within all the five problem domains; further, differences were found between groups on the existence of problems in general. Table 3 presents summary of the ANOVA results of types of disability. To determine the source of differences between groups, a HSD Tukey test was used (Table 4). 
Table 3. One-Way ANOVA summary of types of disability

\begin{tabular}{lll}
\hline Domain & $F$ & $\alpha$ \\
\hline Problems related to training institution & 3.79 & 0.025 \\
Problems related to university program & 4.20 & 0.017 \\
Problems related to special education trainers/instructors & 3.61 & 0.030 \\
Problems related to practicum plan and its requirements & 7.03 & 0.001 \\
Problems related to trainees & 4.16 & 0.017 \\
Overall problems & 7.39 & 0.001 \\
\hline
\end{tabular}

$\alpha=.05$.

Table 4. HSD Tukey test summary of types of disability

\begin{tabular}{llll}
\hline & LD & MR & Other disabilities \\
\hline LD & & A, B, C, D, F & \\
MR & A, B, C, D, F & & E, F \\
Other disabilities & & E, F & \\
\hline
\end{tabular}

$\mathrm{A}=$ Problems related to training institution;

$\mathrm{B}=$ Problems related to university program;

$\mathrm{C}=$ Problems related to special education trainers/instructors;

$\mathrm{D}=$ Problems related to practicum plan and its requirements;

$\mathrm{E}=$ Problems related to trainees;

$\mathrm{F}=$ Overall problems.

Post hoc test indicates that differences existed on higher levels in the case of students serving learning disabilities (LD) of students serving mental retardation (MR) on the first (A), second (B), third (C), fourth (D) problem domains, and problems in general $(\mathrm{F})$. However, problems $\mathrm{E}$ and $\mathrm{F}$ were significantly higher in the case of students servings other types of disability of students serving with MR. Table 5 presents types of disability descriptive information.

Table 5. Types of disability descriptive information

\begin{tabular}{lllllll}
\hline Domain & \multicolumn{3}{c}{ MR } & \multicolumn{2}{c}{ LD } & \multicolumn{3}{c}{ Other } \\
\cline { 2 - 7 } & Mean & SD & Mean & SD & Mean & SD \\
\hline Problems related to training institution & 1.79 & 0.52 & 2.08 & 0.52 & 1.97 & 0.60 \\
Problems related to university program & 2.37 & 0.48 & 2.68 & 0.58 & 2.58 & 0.58 \\
Problems related to special education trainers/instructors & 1.61 & 0.34 & 1.90 & 0.64 & 1.85 & 0.60 \\
Problems related to practicum plan and its requirements & 1.81 & 0.44 & 2.19 & 0.56 & 2.03 & 0.55 \\
Problems related to trainees & 1.74 & 0.48 & 1.92 & 0.49 & 2.05 & 0.52 \\
Overall problems & 1.83 & 0.29 & 2.12 & 0.42 & 2.06 & 0.44 \\
\hline
\end{tabular}

To examine any significant differences between different types of training institution groups, another ANOVA was used. Table 6 presents problems found significant between groups (A, C, and F). In addition, a post hoc test was used to determine the source of significant differences between groups. Tables 7 and 8 present summary of HSD Tukey and descriptive information, respectively. Post hoc test indicate a significant present of problems A, $\mathrm{C}$, and $\mathrm{F}$ in public resource room in favor of public special education centers; the same can be said about private resource room. Nevertheless, problems presented significantly higher in private special education centers than it 
is in public ones.

Table 6. One-Way ANOVA summary of type of training institution

\begin{tabular}{lll}
\hline Domain & $F$ & $\alpha$ \\
\hline Problems related to training institution & 6.42 & 0.000 \\
Problems related to special education trainers/instructors & 4.89 & 0.003 \\
Overall problems & 5.03 & 0.002 \\
\hline$\alpha=.05$. & &
\end{tabular}

Table 7. HSD Tukey test summary of types of training institution

\begin{tabular}{lll}
\hline & Public special education centers & Private special education centers \\
\hline Public resource room & A, C, F & \\
Private resource room & A, C, F & \\
Public special education centers & & C \\
\hline
\end{tabular}

$\mathrm{A}=$ Problems related to training institution;

$\mathrm{B}=$ Problems related to university program;

$\mathrm{C}=$ Problems related to special education trainers/instructors;

$\mathrm{D}=$ Problems related to practicum plan and its requirements;

$\mathrm{E}=$ Problems related to trainees;

$\mathrm{F}=$ Overall problems.

Table 8. Types of training institution descriptive information

\begin{tabular}{|c|c|c|c|c|c|c|c|c|}
\hline \multirow[t]{2}{*}{ Domain } & \multicolumn{2}{|c|}{$\begin{array}{l}\text { Public resource } \\
\text { room }\end{array}$} & \multicolumn{2}{|c|}{$\begin{array}{c}\text { Private } \\
\text { resource room }\end{array}$} & \multicolumn{2}{|c|}{$\begin{array}{c}\text { Public special } \\
\text { education centers }\end{array}$} & \multicolumn{2}{|c|}{$\begin{array}{c}\text { Private special } \\
\text { education centers }\end{array}$} \\
\hline & Mean & SD & Mean & SD & Mean & $\mathrm{SD}$ & Mean & SD \\
\hline $\begin{array}{l}\text { Problems related to training } \\
\text { institution }\end{array}$ & 2.02 & 0.49 & 2.29 & 0.47 & 1.65 & 0.53 & 1.96 & 0.58 \\
\hline $\begin{array}{l}\text { Problems related to special } \\
\text { education trainers/instructors }\end{array}$ & 1.85 & 0.59 & 2.05 & 0.63 & 1.49 & 0.36 & 1.83 & 0.54 \\
\hline Overall problems & 2.08 & 0.43 & 2.21 & 0.32 & 1.81 & 0.35 & 2.01 & 0.41 \\
\hline
\end{tabular}

ANOVA test was used to examine whether problems presented significantly between groups of different universities students currently attending. Table 9 presents ANOVA results summary of universities students attending. Significant differences were found between groups on problem domains A, C, D, E, and F. A post hoc test was used to find out the source of differences between groups of universities students currently attending (Table 10). Table 10 indicates that students enrolled at AHU experience less difficulty on domain problems A, C, $\mathrm{E}$, and $\mathrm{F}$ than students enrolled at JU. Further, AHU students experience less difficulty on domain problems A, C, $\mathrm{D}$, and $\mathrm{F}$ than students enrolled at BAU; whereas, students enrolled at BAU experienced significantly higher level of problems related to trainer/supervisor than students enrolled at MU. Students enrolled at AHU experienced significantly less levels of problems A, C, D, E, and F than students enrolled at MU. Table 11 presents university student enrolled descriptive information. 
Table 9. One-Way ANOVA summary of university student enrolled

\begin{tabular}{llc}
\hline Domain & $F$ & $\alpha$ \\
\hline Problems related to training institution & 10.88 & 0.000 \\
Problems related to special education trainers/instructors & 20.78 & 0.000 \\
Problems related to practicum plan and its requirements & 4.09 & 0.008 \\
Problems related to trainees & 5.45 & 0.001 \\
Overall problems & 9.90 & 0.000 \\
\hline$\alpha=.05$. & &
\end{tabular}

Table 10. HSD Tukey test summary of university student enrolled

\begin{tabular}{|c|c|c|c|}
\hline & BAU & MU & AHU \\
\hline JU & & & $\mathrm{A}, \mathrm{C}, \mathrm{E}, \mathrm{F}$ \\
\hline BAU & & $\mathrm{C}$ & $\mathrm{A}, \mathrm{C}, \mathrm{D}, \mathrm{F}$ \\
\hline MU & & & $\mathrm{A}, \mathrm{C}, \mathrm{D}, \mathrm{E}, \mathrm{F}$ \\
\hline
\end{tabular}

$\mathrm{A}=$ Problems related to training institution;

$\mathrm{B}=$ Problems related to university program;

$\mathrm{C}=$ Problems related to special education trainers/instructors;

$\mathrm{D}=$ Problems related to practicum plan and its requirements;

$\mathrm{E}=$ Problems related to trainees;

$\mathrm{F}=$ Overall problems.

Table 11. University student currently enrolled descriptive information

\begin{tabular}{|c|c|c|c|c|c|c|c|c|}
\hline \multirow[t]{2}{*}{ Domain } & \multicolumn{2}{|c|}{$\mathrm{JU}$} & \multicolumn{2}{|c|}{ BAU } & \multicolumn{2}{|c|}{ MU } & \multicolumn{2}{|c|}{ AHU } \\
\hline & Mean & SD & Mean & SD & Mean & SD & Mean & SD \\
\hline Problems related to training institution & 2.12 & 0.57 & 2.08 & 0.47 & 2.10 & 0.50 & 1.55 & 0.42 \\
\hline Problems related to university program & 2.48 & 0.52 & 2.70 & 0.69 & 2.46 & 0.50 & 2.69 & 0.57 \\
\hline $\begin{array}{l}\text { Problems related to special education } \\
\text { trainers/instructors }\end{array}$ & 1.93 & 0.56 & 2.21 & 0.57 & 1.80 & 0.38 & 1.30 & 0.33 \\
\hline $\begin{array}{l}\text { Problems related to practicum plan and its } \\
\text { requirements }\end{array}$ & 1.99 & 0.50 & 2.23 & 0.72 & 2.19 & 0.52 & 1.82 & 0.39 \\
\hline Problems related to trainees & 1.93 & 0.46 & 1.92 & 0.53 & 2.10 & 0.52 & 1.64 & 0.44 \\
\hline Overall problems & 2.07 & 0.37 & 2.21 & 0.48 & 2.10 & 0.36 & 1.73 & 0.31 \\
\hline
\end{tabular}

Finally, a t-test was used to examine the effect of hours credited for practicum training on the existence of problems. Although students may be credited 3, 6, 9, or 12 hours per training course; most students responded that they either should be credited 6 or 12 hours by the end of the semester. However, two students responded that they will be credited 3 and 4 hours, respectively, and they were excluded for the statistical analysis. Results indicated that students accredited 6 hours reported significantly higher levels of problems on all the five domains and problems in general with the exception of problems related to university programs, where students credited 12 hours reported relatively higher levels of problems. Table 12 presents t-test results summary of credited hours groups. 
Table 12. T-test summary of credited hours groups

\begin{tabular}{|c|c|c|c|c|c|c|}
\hline Domains & $\begin{array}{l}\text { Credited } \\
\text { hours }\end{array}$ & Mean & SD & $\mathrm{t}$ & $\mathrm{df}$ & $\alpha$ \\
\hline \multirow{2}{*}{ Problems related to training institution } & 6 & 2.0908 & 0.48597 & \multirow{2}{*}{2.09} & \multirow{2}{*}{146} & \multirow{2}{*}{0.038} \\
\hline & 12 & 1.8974 & 0.57747 & & & \\
\hline \multirow{2}{*}{ Problems related to university program } & 6 & 2.5234 & 0.56522 & \multirow{2}{*}{-0.69} & & \multirow{2}{*}{0.490} \\
\hline & 12 & 2.5897 & 0.56641 & & & \\
\hline \multirow{2}{*}{$\begin{array}{l}\text { Problems related to special education } \\
\text { trainers/instructors }\end{array}$} & 6 & 1.9552 & 0.47666 & \multirow{2}{*}{2.62} & & \multirow{2}{*}{0.010} \\
\hline & 12 & 1.7086 & 0.59779 & & & \\
\hline \multirow{2}{*}{$\begin{array}{l}\text { Problems related to practicum plan and its } \\
\text { requirements }\end{array}$} & 6 & 2.1879 & 0.59167 & \multirow{2}{*}{2.62} & & \multirow{2}{*}{0.010} \\
\hline & 12 & 1.9494 & 0.50038 & & & \\
\hline \multirow{2}{*}{ Problems related to trainees } & 6 & 2.0360 & 0.53497 & \multirow{2}{*}{2.60} & & \multirow{2}{*}{0.010} \\
\hline & 12 & 1.8165 & 0.47293 & & & \\
\hline \multirow{2}{*}{ Overall problems } & 6 & 2.1342 & 0.39077 & \multirow{2}{*}{2.60} & & \multirow{2}{*}{0.010} \\
\hline & 12 & 1.9569 & 0.40864 & & & \\
\hline
\end{tabular}

\section{Discussion and Recommendations}

Results indicate no differences between male and female future special education teacher responses on the survey. There were no studies found in the literature on the effect of gender in the existence of such problems. However, findings suggest that both genders do experience the same level of problems. It is recommended to investigate in-depth such influence on a larger and more representative sample.

Preservice teachers serving different types of disability categories indicated having problems on all domains although those serving student with LD had more pronounced problems related to the training institution, university programs, trainers, practicum plan, and problems in general. These findings are consistent with the finding of previous studies found in the literature (e.g. Yahia, 2006; Brownell et al., 2008; Goe, 2007; Alghoni, 1990; Ammar, 1997; Diab, 1999). It is documented in these studies that preservice teachers face different kinds of problems, but none have been connected to serving a specific kind of disability. It is also noted that about $46 \%$ of the study sample consisted of preservice teachers serving children with LD. Additionally; preservice teachers do not see themselves as a source of any problem. On the contrary, preservice teachers serving students with other types of disability categories were experiencing higher levels of problems in general and see themselves as a source of problems. This may be due to the difficult nature of disabilities they are serving (e.g. autism, hearing impairment, health impairment, etc.); most preservice teachers take no more than one course work in related with hearing impairment, for example, but there is heavy emphasis on courses related to mild/moderate LD and MR (Al-hiary \& Kinnison, 2008). Preservice teachers may have found many differences between practice and theory in their classrooms. However, students serving children with MR experienced the least levels of problems. This finding can be attributed to the heavy emphasis of course work preparation (Al-Khatib, 2007; Zeitone \& Obidat, 1984) before doing practicum and to the longer periods of emphasis on serving individuals with MR. MR was one of the first disabilities to be served in Jordan; services are considered one of the best for those students. Moreover, most other courses (such as methodology and diagnosis) place heavy effort preparing students working with mild and moderate disabilities (e.g. LD and MR). Indeed, further and deeper research is needed to examine types of disability effects on preservice teachers and training programs.

Preservice teachers completing their practicum in public and private resource rooms indicated that they were experiencing problems related to their institution and practicum instructor on higher levels than those at public special education centers. The literature documented some studies about the role and the impact of support provided by institution and training teacher in the success of field experiences (e. g. Hanline, 2010; Brownell et al., 2008; Goe, 2007; Ammar, 1997; Al-Qahtani, 1994; Osunde, 1996), other studies documented that preservice teachers felt less prepared to meet the challenges associated with teaching children with special needs (Brownell et al., 2008; Guyton \& McIntyre, 1990; Ammar, 1997; Diab, 1999; Alghoni, 1990). Al-hiary and Kinnison (2008) noted that many of those special education teachers working in resource rooms are not certified in special education and many come from other disciplines (e.g. Language art). Those teachers have not received the 
proper and sufficient training to meet the needs of their students, and provide experiences and guidance for preservice teachers. These reasons may be the cause of this finding since that most of students were doing their practicum in resource rooms. Additionally, participants expressed higher levels of problems in private special education centers related to their trainers/instructors than those in public special education centers. Such findings suggest the need for reviewing and improving the quality of practicum training and those who are in charge of supervising and training preservice teachers. Moreover, orientation should be provided for training institutions about what preservice teachers needs to do, how, and when; both institute and student need to be oriented about how to cooperate and comply with the practicum plan. Additionally, many of the private special education centers are taking their job more seriously. It is not doubt that both are working toward benefiting the child and his family, but private ones are commercially based and that can imply some procedures and measures that comply with the center policy; but it is not necessary for the child and his family. That can be a source of conflict.

Preservice teachers enrolled at AHU indicated fewer problems related to training institution, instructors, themselves, and in general than students enrolled at JU. Participants enrolled at BAU indicated higher levels of problems related to training institution, instructors, practicum plan, and in general than students enrolled at AHU. Preservice teachers enrolled at AHU indicated fewer problems related to training institution, instructors, practicum plan, themselves, and in general than individuals enrolled at MU. Finally, students enrolled at BAU indicated higher levels of problems related to their instructors than students enrolled at MU. AHU has established the latest special education program and tried to benefit from the previous universities experiences (JU, MU, and BAU).Thus, special education program at AHU is trying to take the best of other programs and build and improve its plan and requirement (theoretical and practicum); AHU reforms its degree-plan every 4 years based on accumulative feedback and emerging trends in the field of special education. Additionally, AHU preservice teachers are distributed in very few schools and special education centers compared to other universities, therefore, the connection between the university and the training institutions have been established a long time ago, and those institutions know practicum requirements and try to comply with them helping students achieve their goals. However, larger, cumulative, and comprehensive samples from different universities are needed to explore the differences between different university programs, including public and private ones newly implementing practicum training. Al-Khatib (2007) indicate that university training programs needs to be reviewed; few years before that, Al-Bataineh (2002) recommended a comprehensive review of teacher preparation programs. Yet, the current findings indicate that such reviews still far behind from professional standards.

Problems were presented in higher levels in the case of preservice teachers who will be credited 6 hours per practicum course in all problem domains and problems in general except in the case of problems related to university program. This later finding suggests that students whom are credited 12 hours may have the chance to experience the impact of the program in action (they work with children five-days a week, 6 hours per day), whereas those participants credited 6 hours do not have the same chance to experience this impact on the same level (they work with children no more than 2 days a week, no longer than 3 hours a day).

As Al-Bataineh (2002) suggested, university programs need to be carefully reviewed and reformed to meet the needs of preservice teachers and the educational system. Further, more research needs to be conducted to identify the variables may enhance the quality of future teachers, and to identify problems faced by preservice teachers in order to adjust practicum plans and universities' policies toward minimizing their effect on these programs. Moreover, universities should reconsider better, more subjective criteria when hiring and assigning instructors for practicum. It is clear that preservice teachers are having problems that need to be addressed. The sample of the study indicated clearly in almost every problem domain some higher level of problems related to their university trainers/instructors. An intensive, deep study of the quality of practicum instructors is needed, indeed, in order to find solutions for this important problem.

Definitely, The Jordanian higher education programs, in respect to special education, needs to be reviewed and reformed. The subjects of the study indicated several problems on different domains; these problems are critical up to the point that can jeopardize the validity of teacher preparation programs in these universities. Large-scale, comprehensive studies are needed to identify problems faced by preservice special education teachers, and to formulate solutions for such problems. Other parties that are involved in the process of teacher preparation programs (e.g. training institutions) need to be researched, as well, and included actively in the process of formulating solutions.

Finally the findings of the current study are limited to its sample and time of data collection. Findings and conclusions should be carefully generalized to other universities and programs. The quality of teacher education 
and teacher preparation programs is highly critical and, thus, need to be researched on larger scale and in more depth. Further, this survey study, as any other survey study, endures limitations correspond with survey instrumentation.

\section{References}

Al-Bataineh, A. (2002). Provisions for students with learning disabilities in Jordanian schools. Paper presented at the American Educational Studies Association Annual Meeting, Pittsburgh, Pennsylvania.

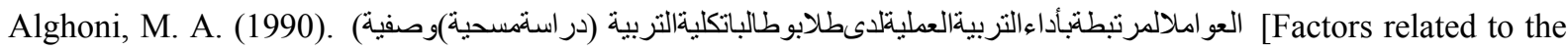
performance of practicum students of the college of education: A survey study]. Journal of King Abdulaziz University for Educational Sciences, 4(3), 209-236.

Al-Hiary, G. M., \& Kinnison, L. (2008). Special Education Teachers Preparation Programs: Jordan and the United States. A Paper presented at the Teacher Education Division-Council for Exceptional Children $31^{\text {st }}$ Annual Conference, Dallas, Texas.

Al-Khatib, J. M. (2007). The impact of training on general education teachers' knowledge and acceptance of inclusion of students with learning disabilities in Jordan. Insight on Learning Disabilities, 4(1), 13-21.

Al-Qahtani, S. A. (1994). The Role and influence of the cooperating teacher on student teachers during student teaching. Risalat Ul-Khaleej Al-Arabi, 15(51), 37-79.

Al-Qemesh, M. N., \& Al-kharabsheh, O. M. (2009). An Evaluation of the practical training programs for special education diploma students in the Jordanian community colleges from trainees' and cooperative teachers' perspectives. Journal of Educational \& Psychological Sciences, 10(1), 40-66.

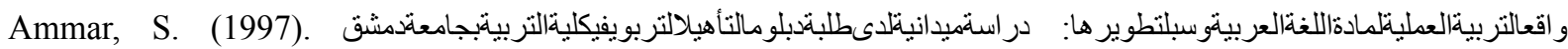
[Current status of Arabic language practicum and how it can be developed: A field study of diploma students at the University of Damascus]. Arab Journal of Education, 17(2), 201-252.

Brownell, J., Ross, D., Colon, E., \& McCallum, C. (2005). Critical features of special education teacher preparation: A comparison with general teacher education. The Journal of Special Education, 38, 242-252. http://dx.doi.org/10.1177/00224669050380040601

Brownell, M. T., Leko, M. M., Kamman, M., \& King, L. (2008). Defining and preparing high-quality teachers in special education: What we know from the research? In T. E. Scruggs, \& M. A. Mastropieri (Eds.), Advances in Learning and behavioral disabilities (Vol. 21, pp. 35-74). Bingley, UK: Emerald Group Publishing Limited.

Carnine, D. (1992). Expanding the notion of teachers' rights: Access to tools that work. Journal of Applied Behavior Analysis, 25, 13-19. http://dx.doi.org/10.1901/jaba.1992.25-13

Carroll, A. (2003). The impact of teacher training in special education on the attitude of Australian preservice general educators towards people with disabilities. Teacher Education Quarterly, 30(3), 65-79.

Clift, R. T., \& Brady, P. (2005). Research on methods courses and field experiences. In M. Cochran-Smith, \& K. Zeichner (Eds), Studying teacher education: The report of the AERA panel on research and teacher education (pp. 309-425). Washington, DC: American Educational Research Association.

Council for Exceptional Children Board of Directors. (2004). CEC Definition of a Well-Prepared Special Education Teacher. Retrieved April 15, 2008, from http://www.cec.sped.org/Content/NavigationMenu/ ProfessionalDevelopment/ProfessionalStandards/well-prepared-final.pdf

D'Rozario, V., \& Wong, A. F. (1998). A study of practicum-related stress in sample of firs year student teachers in Singapore. Asia-Pacific Journal of Teacher Education, 1(1), 39-52.

Darling-Hammond, L. (2000). Studies of excellence in teacher education. New York, NY: National Commission on Teaching and America's Future.

Diab, T. (1999). Attitudes of student teachers towards the practical education programme at the University of Jordan: An evaluation study. Dirasat, 26(1), 142-163.

Edwards, M. (1993). What is wrong with the practicum: Some reflections. South Pacific Journal of Teacher Education, 21(1), 33-43. http://dx.doi.org/10.1080/0311213930210105

El Astal, I. H. (2004). Problems facing student teachers at the College of Education-Ajman University for Science and Technology. Journal of Educational Sciences, 3(6), 143-181.

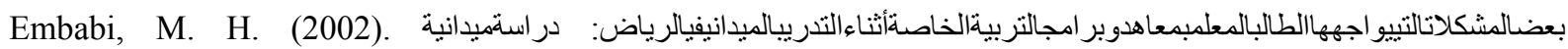


[Problems faced by student teachers in special education institutions and programs during practicum training in Riyadh: A field study]. Journal of Special Education Academy, 1, 105-157.

Englert, C. S., Tarrant, K. L., \& Mariage, T. V. (1992). Defining and redefining instructional practice in special education: Prospective on good teaching. Teacher Education and Special Education, 15, 62-86. http://dx.doi.org/10.1177/088840649201500203

Fueyo, V., Koorland, M. A., \& Rasch, K. (2008). A conceptual framework for analyzing issues and dilemmas in the preparation of special education teachers. In T. E. Scruggs, \& M. A. Mastropieri (Eds.), Advances in Learning and behavioral disabilities (Vol. 21, pp. 1-33). Bingley, UK: Emerald Group Publishing Limited.

Goe, L. (2007). The link between teacher quality and student outcomes: A research synthesis. A Report from the National Comprehensive Center for Teacher Quality (NCCTQ).

Grant, C. A., \& Gillette, M. (2006). A candid talk to teacher educators about effectively preparing teachers who can teach everyone's child. Journal of Teacher Education, 57, 292-299. http://dx.doi.org/10.1177/0022487105285894

Guyton, E., \& McIntyre, J. (1990). Student teaching and school experience. In W. R. Housten (Ed.), Handbook of research on teacher education (pp. 514-534). New York: MacMillan publishing company.

Hadidi, M. S. (1990). A survey of special education teachers need for in-service training programs in the Hashemite Kingdom of Jordan. Derasat, 17(1), 145-172.

Hadidi, M. S. (1993). The effect of in-service training programs provided for special education teachers in Jordan. Derasat, 20(2), 170-194.

Hanline, M. F. (2010). Preservice teachers' perception of field experiences in inclusive preschool setting: Implications for personnel preparation. Teacher Education and Special Education, 33(4), 335-351. http://dx.doi.org/10.1177/0888406409360144

International Reading Association. (2003). Prepared to make a difference: An executive summary of the National Commission on Excellence in Elementary Teacher Preparation for Reaching Instruction. Newark, DE: IRA.

MacDonald, C. J. (1993). The multiplicity of factors creating stress during the teaching practicum. The Student Teachers Perspective Education, 113(1), 48-58.

McLoughlin, S. A., \& Maslak, M. (2003). Prospective teachers' perceptions of development during fieldwork: Tutoring as a vehicle for professional growth. The Teacher Educator, 38, 267-284. http://dx.doi.org/10.1080/08878730309555323

O’Brian, M., Stoner, J., Appel, K., \& House, J. J. (2007). The first field experience: Perspectives of preservice and cooperating teachers. Teacher Education and Special Education, 30, 264-275. http://dx.doi.org/10.1177/088840640703000406

Osunde, E. O. (1996). The effect of student teachers of the teaching behaviors of cooperative teachers. Education, $116(4), 612-619$.

Perham, H. J. (1984). Preparation for Leadership in preparation. Teacher Education and Special Education, 7, 59-65. http://dx.doi.org/10.1177/088840648400700201

Samdi, J., \& Al-nhar, T. (2001). Mastery level of effective teaching skills among special education teachers in United Arab Emirates. The Educational Research Center Journal, 19, 193-216.

Sears, S., Cavallaro, C., \& Hall, S. (2004). Quality early field experiences for undergraduates. Teacher Education and Special Education, 27, 75-79. http://dx.doi.org/10.1177/088840640402700108

Socket, H. (1990). The school curriculum: A basis for partnership. British Journal of Educational Studies, 35, 30-43. http://dx.doi.org/10.1080/00071005.1987.9973749

Warger, C., \& Aldinger, L. (1984). Improving student teacher supervision: The preservice consultation model. TEASE, 7, 155-163.

Whitney, L., Golez, F., Nagel, G., \& Nieto, C. (2002). Listening to voices of practicing teachers to examine the effectiveness of a teacher education programs. Action in Teacher Education, 23, 69-76. http://dx.doi.org/10.1080/01626620.2002.10463090

Wideen, M., Mayer-Smith, J., \& Moon B. (1998). A critical analysis of the research on learning to teach. Review of Educational Research, 68, 130-178. http://dx.doi.org/10.3102/00346543068002130 
Yahia, K. A. (2006). Educational programs for individuals with special needs. Amman, Jordan: Dar Almaseera for Publishing and Distribution.

Yesseldyke, J. E., \& Algozzine, B. (1982). Critical issues in special and remedial education. Boston: Houghton Mifflin company.

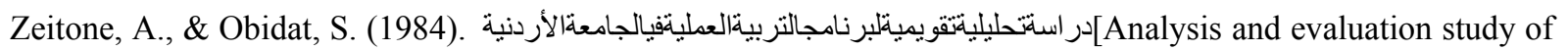
practicum training program in the University of Jordan]. Dirasat, 11(6), 157-163.

\section{Copyrights}

Copyright for this article is retained by the author(s), with first publication rights granted to the journal.

This is an open-access article distributed under the terms and conditions of the Creative Commons Attribution license (http://creativecommons.org/licenses/by/3.0/). 